\title{
Pengetahuan dan Ekspresi Emosi Keluarga serta Frekuensi Kekambuhan Penderita Skizofrenia
}

\section{Knowledge and Family Expressed Emotion and Schizophrenic Patients Relapse Frequency}

\author{
Surya Mulya Fadli, Mitra
}

Program Studi Magister Ilmu Kesehatan Masyarakat Sekolah Tinggi Ilmu Kesehatan Hang Tuah Pekanbaru

\begin{abstract}
Abstrak
Skizofrenia merupakan gangguan psikotik yang bersifat kronis dan selalu mengalami kekambuhan. Tujuan penelitian adalah untuk mengetahui hubungan faktor keluarga dan kepatuhan minum obat dengan kekambuhan penderita skizofrenia di Rumah Sakit Jiwa Tampan Provinsi Riau tahun 2012. Desain penelitian ini adalah cross sectional study dengan ukuran sampel adalah 50 responden dari keluarga penderita skizofrenia yang berkunjung di poliklinik rawat jalan Rumah Sakit Jiwa Tampan. Analisis data dilakukan secara univariat, bivariat dengan korelasi, regresi linier sederhana, dan uji t independen, multivariat dengan uji regresi linier ganda. Variabel yang berhubungan dengan frekuensi kekambuhan penderita skizofrenia adalah pengetahuan keluarga dan ekspresi emosi keluarga. Pengetahuan keluarga berpengaruh paling besar dengan koefisien beta sebesar $-0,461$. Variabel confounding adalah sikap keluarga, dukungan keluarga dan kepatuhan minum obat. Nilai $\mathrm{R}^{2}$ diketahui sekitar $68,7 \%$. Keluarga diharapkan dapat meningkatkan pengetahuan dengan mengikuti penyuluhan dan mengikuti proses keperawatan ketika penderita di rumah sakit jiwa sehingga keluarga memperoleh informasi dalam menangani pasien skizofrenia. Dengan menjaga ekspresi emosi keluarga yang tidak berlebihan, frekuensi kekambuhan pada penderita skizofrenia berkurang. Kata kunci: Ekspresi emosi keluarga, frekuensi kekambuhan, pengetahuan, skizofrenia
\end{abstract}

\footnotetext{
Abstract

Schizophrenia is a psychotic disorder that is chronic and always had a relapse. This study aims to determine the factors associated with the frequency of relapse in patients with schizophrenia in Mental Hospital Tampan, Riau Province 2012. The research design was cross sectional study, with 50 samples of Schizophrenia patient's family who visited in Polyclinic of Mental Hospital Tampan. Data analysis was performed by univariate, bivariate with correlation, simple linear regression, and t-test, multivariate by multiple linear regression tests. The results obtained that the
}

variables associated to the frequency of relapse in patients with schizophrenia are family's knowledge, family's emotional expression. Family's knowledge has the biggest effect with beta coefficient is -0.461 . Confounding variable are family's attitude, family's support, and the obedience of taking medicine. $\mathrm{R}^{2}$ score is $68.7 \%$. The family was suggested to increase the knowledge by following the counseling and follow the caring process while the patient in mental hospital, so that families get information in dealing skizophrenia patient. Family emotional expression that is not excessive, so the frequency of relapse in patients with schizophrenia was decreased.

Keywords: Family's emotional expression, frequency of relapse, family's knowledge, schizophrenia

\section{Pendahuluan}

Skizofrenia adalah suatu sindrom klinis berbagai keadaan psikopatologis yang sangat mengganggu, melibatkan proses pikir, emosi, persepsi, dan tingkah laku dengan insidensi pada pria lebih besar daripada wanita. ${ }^{1}$ Skizofrenia terkait dengan stres, gangguan neurobiologis yang ditandai dengan gangguan pikiran. ${ }^{2}$ Data menunjukkan bahwa $1 \%$ populasi penduduk dunia menderita skizofrenia. ${ }^{3-5}$ Skizofrenia lebih sering terjadi pada populasi urban dan pada kelompok sosial ekonomi rendah. ${ }^{6}$ Di seluruh dunia, skizofrenia tidak terdistribusi merata secara geografis. Secara historis, prevalensi skizofrenia di timur laut dan barat Amerika Serikat dilaporkan lebih tinggi daripada daerah lain. ${ }^{7}$ Derajat keparahan skizofrenia lebih besar di negara maju dari-

Alamat Korespondensi: Mitra, Prodi Kesehatan Masyarakat Sekolah Tinggi Ilmu Kesehtan Hang Tuah Pekanbaru, Jl. Mustafa Sari No. 5, Tangkerang Selatan Pekanbaru Riau, Hp.08126731772,e-mail: mitra_harau@yahoo.co.id 
pada negara berkembang. Di Rumah Sakit Jiwa Tampan Provinsi Riau, jumlah penderita gangguan jiwa rawat inap dan rawat jalan pada tahun 2009, 2010, dan 2011 terlihat berfluktuasi. Kasus skizofrenia merupakan yang terbanyak dibandingkan kasus gangguan jiwa yang lain (75,63\%). Pada periode 2009 - 2011, rata-rata proporsi kekambuhan pasien skizofrenia adalah $83,56 \%$.

Kekambuhan (relapse) adalah kondisi pemunculan kembali tanda dan gejala satu penyakit setelah mereda. ${ }^{8}$ Sekitar 33\% penderita skizofrenia mengalami kekambuhan dan sekitar 12,1\% kembali mengalami rawat inap. ${ }^{9}$ Penyakit skizofrenia cenderung menjadi kronis, sekitar 20 hingga $40 \%$ penderita skizofrenia yang diobati belum menunjukkan hasil yang memuaskan. ${ }^{10}$ Beberapa faktor yang memengaruhi kekambuhan penderita skizofrenia, antara lain meliputi ekspresi emosi keluarga, pengetahuan keluarga, ketersediaan pelayanan kesehatan, dan kepatuhan minum obat. ${ }^{11}$

Pada tahun 2009, 2010, dan 2011, proporsi penderita yang menjalani rehospitalisasi di Rumah Sakit Jiwa Tampan Provinsi Riau rata-rata 83,56\% merupakan penderita skizofrenia yang mengalami kekambuhan. Tujuan penelitian adalah untuk mengetahui hubungan faktor keluarga dan kepatuhan minum obat dengan kekambuhan penderita skizofrenia di Rumah Sakit Jiwa Tampan Provinsi Riau tahun 2012. Setiap kekambuhan berpotensi membahayakan pasien dan keluarga sehingga pasien cenderung dirawat inap kembali dan membutuhkan biaya yang tinggi. Tujuan penelitian untuk mengetahui faktor-faktor yang berhubungan dengan frekuensi kekambuhan penderita skizofrenia di Rumah Sakit Jiwa Tampan Provinsi Riau tahun 2012.

\section{Metode}

Penelitian ini menggunakan desain penelitian kuantitatif cross sectional. Populasi adalah keluarga penderita skizofrenia yang berkunjung di poliklinik rawat jalan Rumah Sakit Jiwa Tampan Provinsi Riau tahun 2012. Besar sampel minimal adalah 50 orang responden yang ditarik secara acak. Keluarga pasien skizofrenia yang ditentukan berdasarkan diagnosis oleh psikiater yang tercatat pada rekam medis pasien minimal dalam periode dua tahun dan tinggal serumah dengan penderita skizofrenia. Data primer dikumpulkan dengan wawancara terstruktur dengan kuesioner tentang variabel independen yang diteliti meliputi pengetahuan keluarga, sikap keluarga, dukungan keluarga, ekspresi emosi keluarga dan kepatuhan minum obat. Variabel sikap, dukungan keluarga dan ekspresi emosi diukur dengan skala likert dengan kategori selalu, sering, jarang dan tidak pernah. Skoring dilakukan dengan mengubah data ordinal (skala likert) menjadi data interval dengan teknik Method of Successive Interval. Analisis data dilakukan secara univariat, bivariat dengan uji korelasi pearson product moment, dan regresi linear sederhana untuk variabel numerik dan uji $\mathrm{T}$ independen untuk variabel kategorik dan analisis multivariat dengan uji regresi linear ganda.

\section{Hasil}

Rata-rata umur penderita skizofrenia di Rumah Sakit Jiwa Tampan adalah 40,26 tahun dengan standar deviasi 13,2 tahun. Jumlah penderita skizofrenia yang berjenis kelamin laki-laki sama banyak dengan jumlah penderita skizofrenia perempuan yaitu 25 orang (50\%). Pada umumnya, pendidikan penderita skizofrenia adalah tamatan SD $(21,42 \%)$, sebagian besar lama sakit penderita skizofrenia $>5$ tahun $(37,74 \%)$. Rata-rata frekuensi kekambuhan penderita skizofrenia dalam dua tahun terakhir adalah 1,48 kali dengan standar deviasi 1,18 kali. Skor untuk variabel pengetahuan diperoleh dari 8 buah pertanyaan dengan rata-rata skor pengetahuan keluarga adalah 4,22 dengan standar deviasi 1,694 . Nilai rata-rata skor sikap keluarga 24,92 dengan standar deviasi 4,294, rata-rata skor dukungan keluarga 23,08 dengan standar deviasi 3,715, rata-rata skor ekspresi emosi keluarga 20,74 dengan standar deviasi 4,238, frekuensi penderita yang patuh minum obat adalah 24 orang $(48 \%)$ dan frekuensi penderita yang tidak patuh minum obat adalah 26 orang (52\%).

Berdasarkan analisis bivariat dengan uji korelasi dan regresi linier sederhana diperoleh bahwa pengetahuan keluarga, sikap keluarga, dan dukungan keluarga mempunyai hubungan yang kuat dan berarah negatif dengan nilai $\mathrm{R}$ masing-masing $-0,747$; $-0,602$; dan $-0,617$. Hal tersebut berarti semakin tinggi pengetahuan keluarga, semakin berkurang frekuensi kekambuhan penderita skizofrenia. Semakin baik sikap keluarga, semakin berkurang frekuensi kekambuhan penderita skizofrenia. Semakin tinggi dukungan keluarga, semakin berkurang frekuensi kekambuhan penderita. Untuk variabel ekspresi emosi keluarga, besar hubungan adalah sedang dengan arah yang positif berarti semakin meningkat ekspresi emosi semakin meningkatkan frekuensi kekambuhan penderita skizofrenia. Variabel kepatuhan minum obat dibagi menjadi dua kategori yaitu patuh dan tidak patuh. Terdapat perbedaan yang signifikan kepatuhan minum obat dengan frekuensi kekambuhan. Nilai rata-rata kekambuhan penderita yang tidak patuh adalah 2,19 kali, sedangkan kekambuhan penderita yang patuh rata rata adalah 0,71 kali (Tabel 1).

Berdasarkan analisis multivariat diperoleh bahwa variabel yang berhubungan dengan kekambuhan penderita skizofrenia adalah pengetahuan keluarga dan ekspresi emosi keluarga. Variabel confounding adalah kepatuhan minum obat, sikap keluarga, dan dukungan keluarga. Variabel yang paling berpengaruh terhadap frekuensi kekambuhan adalah pengetahuan keluarga 
Tabel 1. Analisis Bivariat Hubungan Faktor Keluarga dan Kepatuhan Minum Obat dengan Frekuensi Kekambuhan Penderita Skizofrenia

\begin{tabular}{lccccc}
\hline Variabel & Mean \pm SD & $\mathbf{n}$ & $\mathbf{R}$ & $\mathbf{R}^{\mathbf{2}}$ & Nilai p \\
\hline Pengetahuan keluarga & - & - & $-0,747$ & 0,558 & 0,0001 \\
Sikap keluarga & - & - & $-0,602$ & 0,363 & 0,0001 \\
Dukungan keluarga & - & - & $-0,617$ & 0,381 & 0,0001 \\
Ekspresi emosi keluarga & - & - & 0,327 & 0,107 & 0,020 \\
Kepatuhan minum obat & & & & & \\
$\quad \begin{array}{l}\text { Tidak patuh } \\
\quad \text { Patuh }\end{array}$ & $2.19 \pm 0,98$ & 26 & - & - & 0,0001 \\
\hline
\end{tabular}

dengan koefisien beta $=-0,461$ setelah dikontrol oleh variabel ekspresi emosi, kepatuhan minum obat, sikap, dan dukungan keluarga. Koefisien determinasi $\left(\mathrm{R}^{2}\right)$ diperoleh 0,687 berarti bahwa model regresi dapat menjelaskan $68,7 \%$ variasi variabel frekuensi kekambuhan penderita skizofrenia. Persamaan regresi berdasarkan hasil tersebut dapat dilihat pada Persamaan 1.

Dengan model persamaan tersebut, dapat diperkirakan frekuensi kekambuhan penderita skizofrenia dengan menggunakan variabel pengetahuan keluarga, sikap keluarga, dukungan keluarga, ekspresi emosi keluarga, dan kepatuhan minum obat. Makna dari koefisien B untuk setiap variabel dapat membuat kekambuhan penderita skizofrenia berkurang atau bertambah. Pengetahuan keluarga yang meningkat dapat mengurangi frekuensi kekambuhan penderita skizofrenia sebanyak 0,026 kali. Sikap keluarga yang positif dan dukungan keluarga yang tinggi juga dapat mengurangi kekambuhan sebanyak 0,042 kali dan 0,047 kali. Ekspresi emosi keluarga yang tinggi dan ketidakpatuhan penderita untuk minum obat dapat meningkatkan kekambuhan sebanyak 0,075 dan 0,368 kali. Pada analisis multivariat, terlihat bahwa variabel yang berhubungan secara bermakna adalah pengetahuan keluarga (nilai $\mathrm{p}=0,0001$ ) dan ekspresi emosi keluarga (nilai $\mathrm{p}=0,042)$ (Tabel 2).

\section{Pembahasan}

Rata-rata kekambuhan penderita skizofrenia dalam dua tahun adalah 1,48 kali dengan standar deviasi 1,18 kali. Tingkat kekambuhan penderita skizofrenia masih terus dipelajari. Studi naturalistik menemukan tingkat kekambuhan kumulatif dalam lima tahun berkisar 70 80\%. ${ }^{12}$ Studi di Hongkong menemukan bahwa dari 93 pasien psikosis, tingkat kekambuhan adalah 21\%, 33\% dan $40 \%$ dalam tahun pertama, kedua, dan ketiga. ${ }^{12}$ Penelitian di wilayah kerja Puskesmas Mantup Lamongan menyatakan bahwa kekambuhan skizofrenia adalah 1 - 2 kali dalam satu tahun. ${ }^{13}$ Rata-rata umur penderita skizofrenia di Rumah Sakit Jiwa Tampan adalah 40,26 tahun dengan standar deviasi 13,2 tahun. Christy, ${ }^{12}$ menyatakan kekambuhan cenderung terjadi pada kelompok umur kurang dari 50 tahun, meskipun tidak dapat diprediksi secara statistik tetapi ada kecenderungan pasien yang lebih muda cenderung kambuh dibandingkan pasien yang lebih tua.

Hasil penelitian menunjukkan tingkat pengetahuan keluarga yang semakin rendah sehingga frekuensi kekambuhan penderita skizofrenia semakin bertambah (standar koefisien beta $=-0,46$ ) setelah dikontrol oleh variabel sikap, dukungan, dan ekspresi emosi keluarga serta kepatuhan minum obat. Penelitian ini sesuai dengan penelitian sebelumnya, pengetahuan keluarga berhubungan signifikan dan berkorelasi negatif dengan kekambuhan pada penderita skizofrenia. ${ }^{14,15}$ Pengetahuan yang perlu dimiliki oleh keluarga antara lain pemahaman tentang gangguan mental yang diderita klien/penyakit skizofrenia, faktor penyebab, cara pemberian obat, dosis obat, dan efek samping pengobatan, gejala kekambuhan, serta sikap yang perlu ditunjukkan dan dihindari selama merawat klien di rumah.

Salah satu faktor penyebab kekambuhan pasien skizofrenia adalah perilaku keluarga yang tidak tahu cara menangani pasien skizofrenia di rumah. ${ }^{16}$ Perawatan di

Persamaan 1. Model Persaamaan Regresi Linier Kekambuhan Penderita Skizofrenia

Frekuensi kekambuhan penderita skizofrenia $=2,757-0,026 *$ pengetahuan keluarga $-0,042 *$ sikap keluarga $-0,047 *$ dukungan keluarga $+0,075 *$ ekspresi emosi keluarga $+0,368 *$ kepatuhan minum obat

Tabel 2. Pemodelan Multivariat Akhir Pengaruh Faktor Keluarga dan Kepatuhan Minum Obat dengan Frekuensi Kekambuhan Penderita Skizofrenia

\begin{tabular}{|c|c|c|c|c|c|}
\hline \multirow{2}{*}{ Variabel } & \multirow{2}{*}{ Nilai p } & \multirow{2}{*}{$\mathbf{R}$} & \multirow{2}{*}{$\mathbf{R}^{2}$} & \multicolumn{2}{|c|}{ Koefisien B } \\
\hline & & & & Unstandardi & andardized \\
\hline Pengetahuan keluarga & 0,0001 & 0,829 & 0,687 & $-0,026$ & $-0,461$ \\
\hline Sikap keluarga & 0,202 & & & $-0,042$ & $-0,152$ \\
\hline Dukungan keluarga & 0,232 & & & $-0,047$ & $-0,148$ \\
\hline Ekspresi emosi keluarga & 0,042 & & & 0,075 & 0,181 \\
\hline Kepatuhan minum obat & 0,182 & & & 0,368 & 0,157 \\
\hline
\end{tabular}


rumah sakit tidak akan bermakna apabila tidak dilanjutkan dengan perawatan di rumah. Untuk dapat melakukan perawatan yang baik dan benar, keluarga perlu mempunyai bekal pengetahuan tentang penyakit yang dialami penderita, salah satunya adalah gangguan fungsi kognitif. Oleh sebab itu, orang terdekat penderita seperti keluarga, pengasuh, dan masyarakat berperan sangat penting dalam penanganan penderita skizofrenia. ${ }^{17}$ Salah satu faktor yang memengaruhi kekambuhan pada penderita skizofrenia adalah pengetahuan keluarga. ${ }^{11}$ Keluarga diharapkan dapat lebih mengerti, mengetahui dan memahami dan pada akhirnya dapat berperan secara aktif sebagai pendukung utama penderita. Selain itu, meningkatkan kemampuan penyesuaian diri serta tidak rentan lagi terhadap pengaruh stressor psikososial. ${ }^{18}$ Sebagian besar keluarga penderita skizofrenia masih kurang memiliki informasi yang memadai tentang skizofrenia, perjalanan penyakit, dan tata laksana untuk mengupayakan rehabilitasi pasien. ${ }^{19}$

Penelitian ini menemukan ekspresi emosi keluarga yang tinggi menyebabkan frekuensi kekambuhan penderita skizofrenia bertambah. Pasien skizofrenia yang tinggal dalam lingkungan keluarga dengan ekspresi emosi yang kuat (highly expressed emotion) atau gaya afektif negatif secara signifikan lebih sering mengalami kekambuhan dibandingkan dengan yang tinggal dalam lingkungan keluarga dengan ekspresi emosi yang rendah (low expressed emotion) atau gaya afektif yang normal. ${ }^{20}$ Apabila keluarga memperlihatkan emosi yang diekspresikan secara berlebih, misalnya klien sering diomeli atau dikekang dengan aturan yang berlebihan, kemungkinan kambuh akan bertambah besar. ${ }^{21}$

Hasil penelitian konsisten dengan penelitian sebelumnya, yaitu ekspresi emosi keluarga berhubungan secara bermakna dan berkorelasi negatif dengan kekambuhan penderita skizofrenia. ${ }^{15}$ Ekspresi emosi keluarga yang tinggi, seperti bermusuhan dan mengkritik, membuat penderita lebih sering kambuh daripada keluarga yang ekspresi emosinya rendah. ${ }^{5}$ Keluarga dengan ekspresi emosi tinggi akan kambuh dalam waktu sembilan bulan dan 57\% kembali dirawat. ${ }^{16}$ Angka kekambuhan di rumah dengan emosi yang diekspresikan rendah dan pasien minum obat teratur sebesar $12 \%$, dengan emosi yang diekspresikan rendah dan tanpa obat $42 \%$, sedangkan emosi yang diekspresikan tinggi dan tanpa obat angka kekambuhan $92 \% .{ }^{7}$

Angka kekambuhan pada penderita skizofrenia yang tinggi disebabkan oleh beberapa faktor, salah satu faktor yang berperan sangat penting adalah ekspresi emosi tinggi keluarga yang ditampilkan kepada penderita, seperti critical comment dan emotional over involvement atau terlalu protektif. Oleh sebab itu, keluarga direkomendasikan untuk tidak menghadapi penderita dengan ekspresi emosi yang berlebihan seperti marah, mengomel, mengkritik, bermusuhan, keras, bicara kasar, terlalu melindungi dan sebagainya karena dapat menyebabkan frekuensi kekambuhan penderita skizofrenia bertambah. Dalam menghadapi dan menangani penderita, keluarga dapat menampilkan ekspresi emosi yang proporsional seperti sabar, menerima penderita, memberikan respons yang positif kepada penderita, menghargai penderita sebagai anggota keluarga dan tidak terlalu melindungi. Program intervensi keluarga terbukti efektif menurunkan tingkat kekambuhan para penderita skizofrenia. ${ }^{22}$

Dukungan dan sikap keluarga serta kepatuhan minum obat menunjukkan hubungan yang bermakna (nilai $\mathrm{p}<0,05$ ). Namun, setelah dilakukan analisis multivariat ketiga variabel bukan merupakan variabel yang berhubungan signifikan dengan frekuensi kekambuhan penderita skizofrenia tetapi merupakan variabel confounding. Pengetahuan keluarga dan ekspresi emosi keluarga merupakan faktor yang memengaruhi frekuensi kekambuhan pada penderita skizofrenia. Faktor lain yang perlu diperhatikan adalah dukungan keluarga, sikap, dan kepatuhan minum obat. Keluarga yang memiliki pengetahuan yang tinggi juga dapat terjadi kekambuhan bila pasien tidak patuh minum obat dan keluarga tidak memantau dan mengawasi pasien minum obat. Perilaku minum obat bagi penderita skizofrenia tergantung pada tingkat kesadaran (insight) dari penderita, misalnya penderita menyangkal atau sadar bahwa dirinya sakit. ${ }^{7}$ Untuk keluarga, harus selalu mengikuti proses perawatan sehingga keluarga dapat memberikan informasi, saran, dukungan, perhatian, mengontrol dan mengawasi penderita minum obat.

\section{Kesimpulan}

Rata-rata frekuensi kekambuhan penderita skizofrenia adalah 1,49 kali dengan standar deviasi 1,182 kali, frekuensi kekambuhan penderita skizofrenia tertinggi dalam dua tahun adalah empat kali. Faktor yang berhubungan signifikan dengan kekambuhan penderita skizofrenia adalah pengetahuan keluarga dan ekspresi emosi keluarga. Apabila pengetahuan keluarga meningkat, frekuensi kekambuhan penderita skizofrenia akan berkurang 0,026 kali. Apabila ekspresi emosi keluarga tinggi, frekuensi kekambuhan penderita skizofrenia akan bertambah 0,075 kali. Variabel yang paling besar pengaruhnya terhadap frekuensi kekambuhan penderita skizofrenia adalah variabel pengetahuan keluarga.

\section{Saran}

Instansi rumah sakit jiwa disarankan membuat kebijakan dan peraturan yang berkaitan dengan program kesehatan jiwa terutama bagi keluarga penderita skizofrenia. Kebijakan tersebut meliputi pember- 
dayaan keluarga dalam mencegah dan mengurangi frekuensi kekambuhan penderita skizofrenia dan ketentuan keluarga penderita skizofrenia untuk mengikuti proses keperawatan selama di rumah sakitsehingga keluarga tahu, mau dan mampu menangani penderita ketika di rumah. Meningkatkan upaya promotif dan preventif melalui program penyuluhan kesehatan, family gathering, kunjungan rumah (home visit), pelatihan kepada keluarga untuk menangani penderita skizofrenia dan program pendampingan keluarga. Selain itu, perlu wadah konsultasi psikologis dan perawatan bagi keluarga penderita skizofrenia sehingga dapat meningkatkan pengetahuan, mampu mengatasi kesulitan dan permasalahan ketika menghadapi penderita di rumah. Pelatihan manajemen emosi diberikan kepada keluarga sehingga keluarga dapat mengendalikan, mengontrol emosi, serta dapat menampilkan ekspresi emosi yang proporsional dalam menghadapi dan menangani penderita skizofrenia.

\section{Daftar Pustaka}

1. Kirkpatrick B, Tek C. Concept of schizophrenia. In: Buchanan RW, Carpenter WT, editors. Comprehensive textbook of psychiatry. 8th ed. New York: Lippincott William \& Wilkins; 2005.

2. Kopelowicz A, Liberman RP, Robert PL, Wallace CJ. Psychiatric rehabilitation for schizophrenia. Int J Psychol Psychology Ther [serial on the internet]. 2003; 3(2): 283-98 [cited 2013 Apr 25]. Available from: www.ijpsy.com/.../psychiatric-rehabilitation-for-schizophrenia

3. American Psychiatric Association. Diagnostic and statistical manual of mental disorders. 4th ed text revision. Washington DC: American Psychiatric Association; 2000.

4. Kazadi NJB, Moosa MYH, Jeenah F. Factors associated with relapse in schizophrenia. South Afr J Psychol [serial on the internet]. 2008; 14(2) [cited 2013 Apr 25]. Available from: www.ajol.info/index.php/sajpsys/article.

5. Kritzinger J, Swarts L, Mall S, Asmal L. Family therapy for schizophrenia in South African contex : challenges and path ways to implementation. South African Journal of Psychology. 2001; 41(2): 140-6.

6. Izzudin A. Konsultasi dan integrasi pelayanan psikiatri: membunuh keluarga sendiri. 2005 [diakses tanggal 29 Desember 2011]. Diunduh dari: www.suaramerdeka.com.

7. Kaplan HI, Sadock BJ, Grebb JA. Sinopsis psikiatri. Kusuma W, penterjemah. Edisi 1. Jakarta: Binarupa Aksara; 2010.

8. Dorland. Ilustrated medical dictionary: kamus kedokteran. Jakarta: EGC; 2002
9. Ucok A, Polat A, Cakir S, Genc A. One year outcome in first episode schizophrenia. Eur Arch of Psych Clin Neurosci [serial on the internet]. 2006; 256: 37-43 [cited 2012 Jun 21]. Available from: www.ncbi.nlm.nih.gov/pubmed.

10. Hawari D. Pendekatan holistik pada gangguan jiwa skizofrenia. Jakarta: Balai Penerbit Fakultas Kedokteran Universitas Indonesia; 2007.

11. Wicaksana I, Jalil A. Faktor-faktor yang mempengaruhi kekambuhan pasien skizofrenia di RSJ. Prof. Dr. Soeroyo Magelang. 2007 [diakses tanggal 5 April 2012]. Diunduh dari: www. pdskijaya.org/abstrak $/$ free\%20paper.

12. Christy LM. Relapse in scizophrenia. Med Bull [serial on the internet]. 2011; 16 (5): 8-9 [cited 2013 Apr 25]. Available from: www.fmshk.org/database/article/03mb2.19.pdf.

13. Patonah S. Hubungan dukungan keluarga dan relapse pada penderita skizofrenia di Wilayah Kerja Puskesmas Mantup Lamongan. Jurnal Penelitian Akademi Kesehatan Rejekwesi Bojonegoro [online]. 2012; 6 (3) [diakses tanggal 21 April 2013]. Diunduh dari: www.journalakes.files.wordpress.com.

14. Nurdiana S, Umbransyah. Peran serta keluarga terhadap tingkat kekambuhan klien skizofrenia. Jurnal Ilmiah Kesehatan Keperawatan. 2007; 3 (1): 41-7.

15. Ryandini FR, Saraswati SH, Meikawati W. Faktor-faktor yang berhubungan dengan kekambuhan pada pasien skizofrenia di Rumah Sakit Jiwa Daerah Dr. Amino Gondohutomo Semarang. Jurnal Keperawatan dan Kebidanan. 2011; 1(4): 205-15.

16. Keliat BA. Peran serta keluarga dalam perawatan klien dengan gangguan jiwa. Jakarta: EGC; 1996.

17. Magaru M. Knowledge, attitude and practices of caragives of patients with schizophrenia in Port Moresby, Papua New Guinea. Pacific J Med Sci [serial on the internet]. 2012; 10 (1) [cited 2013 Apr 25]. Available from: www.pacjmedsci.com.

18. Wulansih S, Widodo A. Hubungan antara tingkat pengetahuan dan sikap keluarga dengan kekambuhan pada skizofrenia di RSJD Surakarta. Berita Ilmu Keperawatan. 2008; 1(4): 181-6.

19. Arif IS. Skizofrenia: memahami dinamika keluarga pasien. Bandung: PT. Refika Aditama; 2006.

20. Kaplan \& Sadock's. Comprehensive textbook of psychiatry. 9th ed. Philadelphia: Lippincott Williams \& Wilkins; 2009.

21. Ingrom IM, Timbury GC. Catatan kuliah psikiatri. Adianto P, penterjemah. Edisi ke-6. Jakarta: EGC; 1995.

22. Asmal L, Mall S, Kritzinger J, Chiliza B, Emsley R. Family therapy for schizophrenia: cultural challenger and implementation barrier ini the South African context. Afr J Psych [serial on the internet]. 2011; 14: 367-71 [cited 2013 Apr 25]. Available from: www.ajop.co.za/journals/Nov2011/Familytherapy.pdf. 